\title{
Synthesis, characterization and cytotoxic activity of palladium (II) carbohydrate complexes
}

\author{
S BHAVYA DEEPTHI ${ }^{\mathrm{a}}$, RAJIV TRIVEDI ${ }^{\mathrm{a}, *}$, P SUJITHA $^{\mathrm{b}}, \mathrm{C}$ GANESH KUMAR ${ }^{\mathrm{b}}$, \\ B SRIDHAR $^{c}$ and SURESH K BHARGAVA ${ }^{\mathrm{d}, \mathrm{e}}$ \\ ${ }^{a}$ Organometallic Chemistry Group, Inorganic and Physical Chemistry Division, ${ }^{\mathrm{b}}$ Chemical Biology \\ Laboratory, Natural Products Chemistry Division, ${ }^{c}$ Laboratory of X-Ray Crystallography, CSIR-Indian \\ Institute of Chemical Technology, Hyderabad 500 607, India \\ ${ }^{\mathrm{d}}$ RMIT-IICT Research Centre, Indian Institute of Chemical Technology, Hyderabad 500 607, India \\ ${ }^{\mathrm{e}}$ Advanced Materials and Industrial Chemistry Group, School of Applied Sciences, Royal Melbourne \\ Institute of Technology University, Melbourne, VIC, 3001, Australia \\ e-mail: trivedi@iict.res.in, rtrajiv401@gmail.com
}

\begin{abstract}
Carbohydrate containing pyridyl triazole ligands, 5-deoxy-1,2- $O$-isopropylidene-5-(4-(2-pyridyl)$1 \mathrm{H}-1,2,3$-triazole-1-yl)- $\alpha$-D-xylofuranose (2a), 3- $O$-Benzyl-5-deoxy-1,2- $O$-isopropylidene-5-(4-(2-pyridyl)- $1 \mathrm{H}$ 1,2,3-triazol-1-yl)- $\alpha$-D-xylofuranose (2b), methyl-5-deoxy-2,3- $O$-isopropylidene-5-(4-(2-pyridyl)-1H-1,2,3triazol-1-yl)- $\beta$-D-ribofuranoside, (2c) and 6-deoxy-1,2:3,4-di- $O$-isopropylidene-6-(4-(2-pyridyl)-1H-1,2,3triazol-1-yl)- $\alpha$-D-galactopyranose (2d) were prepared by the 'click' reaction of 2-ethynyl pyridine with the corresponding azides. The palladium complexes were synthesised by the reaction of pyridyl triazole ligands with $\left[\mathrm{Pd}(\mathrm{COD}) \mathrm{Cl}_{2}\right]$ in dichloromethane. All the compounds were characterized by NMR, IR, mass and elemental analysis. Structural characterization of the ligand 2a was done by X-ray crystallography. The ligands and complexes were tested for their cytotoxic activity on different cell lines like A549 (human alveolar adenocarcinoma cells), Neuro2a (mouse neuroblastoma cells), HeLa (cervical carcinoma cancer cells), MDA-MB-231 (human breast adenocarcinoma cells) and MCF7 (human breast adenocarcinoma cells). The complexes showed considerable cytotoxicity while the ligands were non-toxic on the tested cell lines.
\end{abstract}

Keywords. Carbohydrate; pyridyl triazole; palladium complexes; cytotoxicity.

\section{Introduction}

Bioinorganic chemistry is a rapidly developing field dealing with the synthesis and biological investigation of inorganic complexes. ${ }^{1-5}$ In inorganic complexes, the central metal ion has a significant role in the development of anticancer metallodrug. Discovery of cytotoxic activity of cisplatin and its analogue such as carboplatin has led to an extensive search of new biologically active metal drugs. Several cisplatin related platinumbased drugs have been synthesised, however high general toxicity and development of platinum-resistance to the drug has become major determinant to its efficacy. Development of palladium (II) containing metallodrug has gained importance due to significant similarity in the coordination behaviour of platinum (II) and palladium (II). ${ }^{6-18}$ However, most of the palladium complexes are less cytotoxic compared to their platinum counterparts, due to faster hydrolysis of palladium complexes leading to highly reactive species that are unable to reach their pharmacological target. ${ }^{19}$

*For correspondence
In order to make the palladium complexes as good cytotoxic agents, it is very important to stabilize the complexes by a strong coordinating nitrogen ligand and a suitable leaving group, which should be nonlabile to maintain the structural integrity of the drug in vivo for long period of time. ${ }^{20,21}$ It is evident from literature that the palladium complexes derived from diamines, amine-imine, di-imines ${ }^{22-26}$ have shown excellent cytotoxicity. Metal complexes derived from the click chelators are known for their cytotoxicity ${ }^{27}$ and have proven versatility in the radiolabelling of biomolecules. ${ }^{28}$ Among various triazole functionalities, (2-pyridyl)-substituted 1,2,3-triazoles are well-known for their metal binding studies ${ }^{29-31}$ and are synthesised easily by the well-known click reaction procedure. ${ }^{32}$

In recent years, synthesis of metallodrugs containing biologically important ligands, especially carbohydrate residues has become an interesting area in antitumour therapy. ${ }^{33}$ Certain carbohydrate containing drugs such as bleomicin and adriamicine are used in antitumour therapy. Compared to the conventional medicines, carbohydrates containing metal drugs are more watersoluble. The resemblance of the carbohydrate fragments 
with the molecules involved in various biological functions enhance the tolerance levels of the organism and these fragments are active constituents of glycoproteins, glycolipids and nucleotides. Several carbohydrate containing metallodrugs are studied for their cytotoxicity $^{34-36}$ and radiolabelling techniques. ${ }^{37}$

Our recent results on the biological studies of ferrocene-carbohydrate conjugates ${ }^{38,39}$ have lead to the design and study of the cytotoxic activity of metal complexes containing carbohydrate ligands. Hence, here we present the detailed synthesis and characterization of the carbohydrate triazole ligands and their Pdcomplexes together with the crystal structures of ligand 2a. The cytotoxic activity of the compounds on all the tested cell lines are reported and discussed.

\section{Experimental}

\subsection{Materials and methods}

The complex formation reactions were performed by standard schlenk techniques under argon atmosphere. All the solvents were purified by standard procedures. 2-Ethynyl pyridine was purchased from Aldrich Co. and the azido sugars were prepared according to the literature procedures. ${ }^{40,41}$ Melting points were determined on Toshniwal melting point apparatus and are uncorrected. Optical rotations were determined on JASCO P120 polarimeter. ${ }^{1} \mathrm{H}$ spectra were recorded for $\mathrm{CDCl}_{3} / \mathrm{CDCl}_{3}$ and $d^{6}$-DMSO solutions on $500 \mathrm{MHz}$ (Innova 500) and $300 \mathrm{MHz}$ (Avance 300) instruments. Chemical shifts for protons were reported by taking TMS as the internal reference. ${ }^{13} \mathrm{C}$ NMR spectra were recorded at $75.5 \mathrm{MHz}$ (Avance 300) and the carbon shifts are referenced to the ${ }^{13} \mathrm{C}$ signal of $\mathrm{CDCl}_{3}$ at $77.0 \mathrm{ppm}$. The coupling constants $(J)$ were expressed in Hz. Infrared spectra were recorded on a Thermo Nicolet Nexus 670 Spectrometer using $\mathrm{KBr}$ discs. The UV-Vis spectra were recorded on Varian Carry 500 spectrophotometer over the range $240-400 \mathrm{~nm}$ using $1 \mathrm{~cm}$ path length cuvettes. Compounds $\mathbf{2 e}$ and $\mathbf{3 e}$ were prepared according to the literature procedures. ${ }^{29}$

\subsection{General procedure for the preparation of 2-pyridyl-carbohydrate triazoles $(\mathbf{2 a}-\mathbf{d})$}

To a suspension of azido sugars, 1a-d $(1.39 \mathrm{mmol})$ in 1:1 mixture of water and tert-butyl alcohol $(8 \mathrm{~mL}), 2$ ethynylpyridine $(0.14 \mathrm{~g}, 1.39 \mathrm{mmol})$ was added dropwise. To this solution, sodium ascorbate $(0.05 \mathrm{~g}$, $0.2 \mathrm{mmol})$ and $\mathrm{CuSO}_{4} .5 \mathrm{H}_{2} \mathrm{O}(0.02 \mathrm{~g}, 0.09 \mathrm{mmol})$ were added. The reaction mixture was allowed to stir vigorously at room temperature till the disappearance of starting materials. The reaction mixture was quenched with saturated $\mathrm{NH}_{4} \mathrm{Cl}$ solution and extracted with $\mathrm{CH}_{2} \mathrm{Cl}_{2}(2 \times 5 \mathrm{~mL})$. The combined organic layers were dried over $\mathrm{Na}_{2} \mathrm{SO}_{4}$ and the removal of solvent under vacuum resulted crude mass, which can be purified using silica column (hexane/ethyl acetate).

\section{2a 5-Deoxy-1,2-O-isopropylidene-5-(4-(2-pyridyl)-} 1H-1,2,3-triazole-1-yl)- $\alpha$-D-xylofuranose, 2a: Treatment of 5-azido-5-deoxy-1,2- $O$-isopropylidene- $\alpha$-Dxylofuranose, $(0.298 \mathrm{~g}, 1.39 \mathrm{mmol}) \mathbf{1 a}$ and 2-ethynyl pyridine $(0.14 \mathrm{~g}, 1.39 \mathrm{mmol})$ resulted $\mathbf{2 a}$ as a pale yellow solid. Yield: $0.38 \mathrm{~g}(81 \%)$; mp: $170^{\circ} \mathrm{C} ;[\alpha]_{\mathrm{D}}{ }^{30}$ (c $\left.0.1, \mathrm{CHCl}_{3}\right)=-24.86$; Anal. calc. for $\mathrm{C}_{15} \mathrm{H}_{18} \mathrm{~N}_{4} \mathrm{O}_{4}$ : C 56.60, H 5.70, N 17.60; found: C 56.71, H 5.18, N 17.94; ${ }^{1} \mathrm{H}$ NMR $\left(\mathrm{CDCl}_{3}+d^{6}\right.$-DMSO, $\left.75.5 \mathrm{MHz}\right): \delta$ $1.28\left(\mathrm{~s}, 3 \mathrm{H}, \mathrm{CH}_{3}\right.$ of $\left.\mathrm{CMe}_{2}\right), 1.41$ (s, $3 \mathrm{H}, \mathrm{CH}_{3}$ of $\left.\mathrm{CMe}_{2}\right)$, $4.19(\mathrm{~d}, 1 \mathrm{H}, J=1.79 \mathrm{~Hz}, \mathrm{H}-3), 4.51(\mathrm{~m}, 2 \mathrm{H}, \mathrm{H}-5)$, $4.59-4.65(\mathrm{~m}, 1 \mathrm{H}, \mathrm{H}-2), 4.77(\mathrm{dd}, 1 \mathrm{H}, J=4.72$ and $9.25 \mathrm{~Hz}, \mathrm{H}-4), 5.58(\mathrm{~d}, 1 \mathrm{H}, J=3.58 \mathrm{~Hz}, \mathrm{OH}), 5.97$ $(\mathrm{d}, 1 \mathrm{H}, J=3.39 \mathrm{~Hz}, \mathrm{H}-1), 7.25(\mathrm{t}, 1 \mathrm{H}, J=7.17$ and $5.09 \mathrm{~Hz}, \mathrm{Py}), 7.79$ (dt, $1 \mathrm{H}, J=1.3$ and $6.4 \mathrm{~Hz}, \mathrm{Py}$ ), $8.09(\mathrm{~d}, 1 \mathrm{H}, J=7.9 \mathrm{~Hz}, \mathrm{Py}), 8.37$ (s, $1 \mathrm{H}$, triazole), 8.57 $(\mathrm{d}, 1 \mathrm{H}, J=4.15 \mathrm{~Hz}, \mathrm{Ar}) ;{ }^{13} \mathrm{C}\left(75.5 \mathrm{MHz}, \mathrm{CDCl}_{3}+d^{6}-\right.$ DMSO): $\delta$ 25.43, 26.03, 48.53, 73,28, 78.56, 84.68, 110.79, 119.20, 122.62, 136.0, 147.2, 148.57, 149.43; ESI-MS (in $\left.\mathrm{CH}_{3} \mathrm{OH}\right): m / z 318[\mathrm{M}+1]^{+}$; IR $(\mathrm{KBr}$, $\mathrm{cm}^{-1}$ ): 3447, 3107, 2984, 1640, 1261, 1027, 804.

$2.2 \mathrm{~b}$ 3-O-Benzyl-5-deoxy-1,2-O-isopropylidene-5-(4(2-pyridyl)-1H-1,2,3-triazol-1-yl)- $\alpha$-D-xylofuranose, $\mathbf{2 b}$ : Treatment of 5-azido-3- $O$-benzyl-5-deoxy-1,2- $O$ isopropylidine- $\alpha$-D-xylofuranose, $(0.423 \mathrm{~g}, 1.39 \mathrm{mmol})$ $\mathbf{1 b}$ and 2-ethynyl pyridine $(0.14 \mathrm{~g}, 1.39 \mathrm{mmol})$ resulted 2b as a pale yellow solid. Yield: $0.49 \mathrm{~g}$ (86\%); mp: $110-115^{\circ} \mathrm{C} ;[\alpha]_{\mathrm{D}}{ }^{30}$ (c 0.5, $\left.\mathrm{CHCl}_{3}\right)=-75.0$; Anal. calc. for $\mathrm{C}_{22} \mathrm{H}_{24} \mathrm{~N}_{4} \mathrm{O}_{4}$ : C 64.69, H 5.92, N 13.72 . Found: C 65.01, H 6.29, N 13.81; ${ }^{1} \mathrm{H}$ NMR $\left(\mathrm{CDCl}_{3}\right.$, $300 \mathrm{MHz}): \delta 1.28\left(\mathrm{~s}, 3 \mathrm{H}, \mathrm{CH}_{3}\right.$ of $\left.\mathrm{CMe}_{2}\right), 1.41$ (s, $3 \mathrm{H}, \mathrm{CH}_{3}$ of $\left.\mathrm{CMe}_{2}\right), 3.96(\mathrm{~d}, 1 \mathrm{H}, J=2.26 \mathrm{~Hz}, \mathrm{H}-3)$, 4.54-4.58 (m, 3H, H-4, H-5), 4.60 (d, $1 \mathrm{H}, J=3.77$, $\mathrm{H}-2), 4.69$ (bs, $1 \mathrm{H}, \mathrm{CH}_{2} \mathrm{Ar}$ ), $4.72(\mathrm{~d}, 1 \mathrm{H}, J=2.26 \mathrm{~Hz}$, $\left.\mathrm{CH}_{2} \mathrm{Ar}\right), 5.90(\mathrm{~d}, 1 \mathrm{H}, J=3.77 \mathrm{~Hz}, \mathrm{H}-1), 7.15(\mathrm{t}, 1 \mathrm{H}$, $J=5.21 \mathrm{~Hz}, \mathrm{Py}), 7.31-7.35(\mathrm{~m}, 5 \mathrm{H}, \mathrm{Ar}), 7.74(\mathrm{dt}$, $1 \mathrm{H}, J=1.2$ and $6.04 \mathrm{~Hz}, \mathrm{Py}) 8.14$ (s, $1 \mathrm{H}$, triazole), $8.17(\mathrm{~d}, 1 \mathrm{H}, J=3.02, \mathrm{Py}), 8.54(\mathrm{~d}, 1 \mathrm{H}, J=4.53$, Py); ${ }^{13} \mathrm{C} \mathrm{NMR}\left(\mathrm{CDCl}_{3}, 75.5 \mathrm{MHz}\right): \delta 26.26,26.79$, 49.22, 72.08, 78.74, 81.60, 82.00, 105.23, 112.0, 120.1, 122.6, 123.17, 128.01, 128.28, 128.66, 136.64, 136.78, 149.31, 148.35, 150.4; ESI-MS (in $\mathrm{CH}_{3} \mathrm{OH}$ ): $m / z 431$ 
$[\mathrm{M}+\mathrm{Na}]^{+}$; IR $\left(\mathrm{KBr}, \mathrm{cm}^{-1}\right): 2967,1727,1622,1453$, 1074, 787.

\section{2c Methyl-5-deoxy-2,3-O-isopropylidene-5-(4-(2-} pyridyl)-1H-1,2,3-triazol-1-yl)- $\beta$-D-ribofuranose, $2 c$ : Treatment of methyl-5-azido-5-deoxy-2,3- $O$-isopropylidene$\beta$-D-ribofuranoside, $(0.304 \mathrm{~g}, 1.39 \mathrm{mmol}) \quad \mathbf{1 c}$ and 2-ethynyl pyridine $(0.14 \mathrm{~g}, 1.39 \mathrm{mmol})$ resulted $2 \mathrm{c}$ as white solid. Yield: $0.36 \mathrm{~g}(77 \%)$; mp: $180-185^{\circ} \mathrm{C} ;[\alpha]_{\mathrm{D}}{ }^{30}$ (c 0.5, $\mathrm{CHCl}_{3}$ ) $=-19.6$; Anal. calc. for $\mathrm{C}_{16} \mathrm{H}_{20} \mathrm{~N}_{4} \mathrm{O}_{4}$ : C 57.82, H 6.07, N 16.86. Found: C 57.51, H 5.78, N 16.36; ${ }^{1} \mathrm{H}$ NMR $\left(\mathrm{CDCl}_{3}+d^{6}\right.$-DMSO, $\left.500 \mathrm{MHz}\right): \delta$ 1.31 (s, $3 \mathrm{H}, \mathrm{CH}_{3}$ of $\left.\mathrm{CMe}_{2}\right), 1.44$ (s, 3H, $\mathrm{CH}_{3}$ of $\mathrm{CMe}_{2}$ ), $3.41\left(\mathrm{~s}, 3 \mathrm{H}, \mathrm{OCH}_{3}\right), 4.51-4.56(\mathrm{~m}, 1 \mathrm{H}, \mathrm{H}-4), 4.59-4.65$ (m, 2H, H-5), $4.67(\mathrm{~d}, 1 \mathrm{H}, J=4.88 \mathrm{~Hz}, \mathrm{H}-3), 4.83$ $(\mathrm{d}, 1 \mathrm{H}, J=4.88 \mathrm{~Hz}, \mathrm{H}-2), 4.98(\mathrm{~d}, 1 \mathrm{H}, J=1.22 \mathrm{~Hz}$, $\mathrm{H}-1), 7.25$ (t, 1H, $J=6.1$ and $4.88 \mathrm{~Hz}, \mathrm{Py}), 7.81(\mathrm{t}$, $1 \mathrm{H}, J=7.32 \mathrm{~Hz}, \mathrm{Py}), 8.10(\mathrm{~d}, 1 \mathrm{H}, J=7.32, \mathrm{Py})$, $8.4(\mathrm{~s}, 1 \mathrm{H}$, triazole $), 8.86(\mathrm{~d}, 1 \mathrm{H}, J=4.53, \mathrm{Py}) ;{ }^{13} \mathrm{C}$ NMR $\left(\mathrm{CDCl}_{3}+d^{6}-\mathrm{DMSO}, 75.5 \mathrm{MHz}\right) \delta: 23.56,25.02$, $51.60,53.92,80.22,83.69,83.48,108.42,110.98$, $118.42,121.87,121.45,135.56,148.72,146.45$, 147.93; ESI-MS (in $\mathrm{CH}_{3} \mathrm{OH}$ ): $\mathrm{m} / z 333[\mathrm{M}+1]^{+}$; IR $\left(\mathrm{KBr}, \mathrm{cm}^{-1}\right)$ : 2967, 1727, 1622, 1453, 1074, 787.

2.2d 6-Deoxy-1,2:3,4-di-O-isopropylidene-6-(4-(2pyridyl)-1H-1,2,3-triazol-1-yl)- $\alpha$-D-galactopyranose, $2 d$ : Treatment of 6-azido-6-deoxy-1,2:3,4-Odiisopropylidine- $\alpha$-D-galactopyranose $\quad(0.396 \mathrm{~g}$, $1.39 \mathrm{mmol}) \mathbf{1 d}$ and 2-ethynyl pyridine $(0.14 \mathrm{~g}$, $1.39 \mathrm{mmol})$ resulted $\mathbf{2 d}$ as white solid. Yield: $0.43 \mathrm{~g}$ (79\%); mp: $185-190^{\circ} \mathrm{C} ;[\alpha]_{\mathrm{D}}{ }^{30}\left(\mathrm{c} 0.5, \mathrm{CHCl}_{3}\right)=-43.7$; Anal. calc. for $\mathrm{C}_{19} \mathrm{H}_{24} \mathrm{~N}_{4} \mathrm{O}_{5}$ : C 58.75, $\mathrm{H}$ 5.77, $\mathrm{N}$ 8.28. Found: C 58.45, H 5.32, N 8.34; ${ }^{1} \mathrm{H}$ NMR $\left(\mathrm{CDCl}_{3}\right.$, $500 \mathrm{MHz}): \delta 1.28\left(\mathrm{~s}, 3 \mathrm{H}, \mathrm{CH}_{3}\right.$ of $\left.\mathrm{CMe}_{2}\right), 1.34(\mathrm{~s}, 3 \mathrm{H}$, $\mathrm{CH}_{3}$ of $\left.\mathrm{CMe}_{2}\right), 1.42\left(\mathrm{~s}, 3 \mathrm{H}, \mathrm{CH}_{3}\right.$ of $\left.\mathrm{CMe}_{2}\right), 1.48(\mathrm{~s}, 6 \mathrm{H}$, $\mathrm{CH}_{3}$ of $\mathrm{CMe}_{2}$ ), $3.50(\mathrm{dd}, 1 \mathrm{H}, J=5.0 \mathrm{~Hz}, \mathrm{H}-3), 4.16$ (dd, $1 \mathrm{H}, J=2.0$ and $6.0 \mathrm{~Hz}, \mathrm{H}-6), 4.23-4.28(\mathrm{~m}, 2 \mathrm{H}$, H-6 and H-2), 4.48 (m, 1H, H-4), $4.60(\mathrm{~m}, 1 \mathrm{H}, \mathrm{H}-5)$, $5.47(\mathrm{~d}, 1 \mathrm{H}, J=5.0 \mathrm{~Hz}, \mathrm{H}-1), 7.16(\mathrm{t}, 1 \mathrm{H}, J=5.0 \mathrm{~Hz}$, Py), $7.72(\mathrm{dt}, 1 \mathrm{H}, J=2.0$ and $6.0 \mathrm{~Hz}, \mathrm{Py}), 8.14(\mathrm{~d}$, $1 \mathrm{H}, J=8.0 \mathrm{~Hz}, \mathrm{Py}), 8.28(\mathrm{~s}, 1 \mathrm{H}$, triazole $), 8.53(\mathrm{~d}$, $1 \mathrm{H}, J=4.0 \mathrm{~Hz}, \mathrm{Py}) ;{ }^{13} \mathrm{C} \mathrm{NMR}\left(\mathrm{CDCl}_{3}, 75.5 \mathrm{MHz}\right)$ : $\delta$ 24.46, 24.82, 25.91, 50.45, 67.0, 70.25 70.73, 70.98, 76.57, 76.99. 109.02, 109.88, 120.19, 122.67, 123.50, 136.76, 147.99, 149.35, 150.35; ESI-MS (in $\mathrm{CH}_{3} \mathrm{OH}$ ): $\mathrm{m} / z 389[\mathrm{M}+1]^{+}$; IR $\left(\mathrm{KBr}, \mathrm{cm}^{-1}\right)$ : 3109, 2984, 2921, 1641, 1379, 1219, 1080, 1007, 814.

\subsection{General procedure for the preparation of palladium complexes $(\mathbf{3 a - d})$}

Under an argon atmosphere, ligand 2a-d $(0.17 \mathrm{mmol})$ and $\left[\mathrm{Pd}(\mathrm{COD}) \mathrm{Cl}_{2}\right] \quad(0.053 \mathrm{~g}, \quad 0.17 \mathrm{mmol})$, were dissolved in dichloromethane $(5 \mathrm{~mL})$. The mixture was allowed to stir at room temperature for $2 \mathrm{~h}$ and the resulting precipitate was collected by filtration. The solid was washed with diethyl ether and dried in vacuum to get the desired palladium complex.

2.3a Synthesis of $\left[\mathrm{PdCl}_{2}(2 \mathrm{a})\right]$ : Treatment of xylofuranose triazole, $(0.053 \mathrm{~g}, 0.17 \mathrm{mmol}) \quad \mathbf{2 a}$ with $\left[\mathrm{Pd}(\mathrm{COD}) \mathrm{Cl}_{2}\right](0.05 \mathrm{~g}, 0.17 \mathrm{mmol})$ resulted 3a as pale yellow solid. Yield: $0.074 \mathrm{~g}$ (78\%); mp: $285-288^{\circ} \mathrm{C}$; Anal. calc. for $\mathrm{C}_{15} \mathrm{H}_{18} \mathrm{Cl}_{2} \mathrm{~N}_{4} \mathrm{O}_{4} \mathrm{Pd}$ : C 36.35, H 3.66, $\mathrm{N}$ 11.30; found: C 35.92, H 3.11, N 11.15; ${ }^{1} \mathrm{H}$ NMR $\left(\mathrm{CDCl}_{3}+d^{6}\right.$-DMSO, 75.5 MHz): $\delta 1.27\left(\mathrm{~s}, 3 \mathrm{H}, \mathrm{CH}_{3}\right.$ of $\left.\mathrm{CMe}_{2}\right), 1.40\left(\mathrm{~s}, 3 \mathrm{H}, \mathrm{CH}_{3}\right.$ of $\left.\mathrm{CMe}_{2}\right), 4.21(\mathrm{~d}, 1 \mathrm{H}$, $J=3.02 \mathrm{~Hz}, \mathrm{H}-3), 4.48(\mathrm{~m}, 2 \mathrm{H}, \mathrm{H}-5), 4.53-4.65$ $(\mathrm{m}, 1 \mathrm{H}, \mathrm{H}-2), 4.86(\mathrm{dd}, 1 \mathrm{H}, J=3.39$ and $10 . .95 \mathrm{~Hz}$, $\mathrm{H}-4), 5.60(\mathrm{~d}, 1 \mathrm{H}, J=4.91 \mathrm{~Hz}, \mathrm{OH}), 5.90(\mathrm{~d}, 1 \mathrm{H}$, $J=3.58 \mathrm{~Hz}, \mathrm{H}-1), 7.65(\mathrm{t}, 1 \mathrm{H}, J=6.98$ and $7.17 \mathrm{~Hz}$, Py), 8.13 (t, $1 \mathrm{H}, J=6.98$ and $6.79 \mathrm{~Hz}, \mathrm{Py}), 8.21$ (d, $1 \mathrm{H}, J=7.36 \mathrm{~Hz}, \mathrm{Py}), 9.09$ (d, 1H, $J=5.66 \mathrm{~Hz}, \mathrm{Py}$ ), 9.15 (s, 1H, triazole); ESI-MS(in $\mathrm{CH}_{3} \mathrm{OH}+\mathrm{DMSO}$ ): $m / z 478$ [M-OH] $^{+}$; IR $\left(\mathrm{KBr}, \mathrm{cm}^{-1}\right): 3500,3087,2984$, 2930, 1624, 1455, 1379, 1074, 1017, 777.

2.3b Synthesis of $\left[\mathrm{PdCl}_{2}(\mathbf{2 b})\right]$ : Treatment of xylofuranose triazole, $(0.069 \mathrm{~g}, \quad 0.17 \mathrm{mmol}) \quad \mathbf{2 b}$ with $\left[\mathrm{Pd}(\mathrm{COD}) \mathrm{Cl}_{2}\right](0.05 \mathrm{~g}, 0.17 \mathrm{mmol})$ resulted $\mathbf{3 b}$ as pale yellow solid. Yield: $0.074 \mathrm{~g}$ (75\%); mp: $270-275^{\circ} \mathrm{C}$; Anal. calc. for $\mathrm{C}_{22} \mathrm{H}_{24} \mathrm{Cl}_{2} \mathrm{~N}_{4} \mathrm{O}_{4} \mathrm{Pd}$ : C 45.11, $\mathrm{H} \mathrm{4.13,} \mathrm{N}$ 9.56. Found: $\mathrm{C} 46.26, \mathrm{H} 3.92, \mathrm{~N} 9.81 ;{ }^{1} \mathrm{H}$ NMR $\left(d^{6}-\right.$ DMSO, 500MHz): $\delta 1.29$ (s, $3 \mathrm{H}, \mathrm{CH}_{3}$ of $\mathrm{CMe}_{2}$ ), 1.41 (s, 3H, $\mathrm{CH}_{3}$ of $\left.\mathrm{CMe}_{2}\right), 4.13$ (d, $\left.1 \mathrm{H}, J=1.22 \mathrm{~Hz}, \mathrm{H}-3\right)$, $4.57\left(\mathrm{~d}, 2 \mathrm{H}, J=2.26 \mathrm{~Hz}, \mathrm{CH}_{2} \mathrm{Ar}\right), 4.63-4.72(\mathrm{~m}, 3 \mathrm{H}$, H-4 and H-5), $4.90(\mathrm{~d}, 1 \mathrm{H}, J=2.41, \mathrm{H}-2), 5.90(\mathrm{~d}, 1 \mathrm{H}$, $J=2.41 \mathrm{~Hz}, \mathrm{H}-1), 7.27$ (m, 1H, Ar), 7.34 (m, 4H, Ar), $7.49(\mathrm{t}, 1 \mathrm{H}, J=6.10$ and $7.32 \mathrm{~Hz}, \mathrm{Py}), 8.08(\mathrm{t}, 1 \mathrm{H}$, $J=7.32 \mathrm{~Hz}, \mathrm{Py}), 8.12(\mathrm{~d}, 1 \mathrm{H}, J=7.32$, Py), 9.02 (s, $1 \mathrm{H}$, triazole), 9.05 (d, $1 \mathrm{H}, J=4.88$, Py); ESI-MS (in $\left.\mathrm{CH}_{3} \mathrm{OH}+\mathrm{DMSO}\right): \mathrm{m} / z 549[\mathrm{M}-\mathrm{Cl}]^{+}$; IR $\left(\mathrm{KBr}, \mathrm{cm}^{-1}\right)$ : 3090, 2934, 1623, 1456, 1377, 1078, 1027, 779.

$2.3 \mathrm{c}$ Synthesis of $\left[\mathrm{PdCl}_{2}(2 \mathrm{c})\right]$ : Treatment of ribofuranose triazole, $(0.056 \mathrm{~g}, 0.17 \mathrm{mmol}) \quad 2 \mathrm{c}$ with $\left[\mathrm{Pd}(\mathrm{COD}) \mathrm{Cl}_{2}\right](0.05 \mathrm{~g}, 0.17 \mathrm{mmol})$ resulted $3 \mathbf{c}$ as pale yellow solid. Yield: $0.067 \mathrm{~g}$ (78\%); $\mathrm{mp}: 280-285^{\circ} \mathrm{C}$; Anal. calc. for $\mathrm{C}_{16} \mathrm{H}_{20} \mathrm{Cl}_{2} \mathrm{~N}_{4} \mathrm{O}_{4} \mathrm{Pd}$ : C 37.70, H 3.96, N 10.99. Found: C 38.14, H 3.72, N 10.82; ${ }^{1} \mathrm{H}$ NMR ( $d^{6}-$ DMSO, $300 \mathrm{MHz}): \delta 1.32\left(\mathrm{~s}, 3 \mathrm{H}, \mathrm{CH}_{3}\right.$ of $\left.\mathrm{CMe}_{2}\right), 1.45$ (s, $3 \mathrm{H}, \mathrm{CH}_{3}$ of $\mathrm{CMe}_{2}$ ), 3.39 (s, 3H, $\left.\mathrm{OCH}_{3}\right), 4.62-4.71$ (m, 3H, H-3 and H-5), 4.83 (m, 2H, H-2 and H-4), 5.01 $(\mathrm{d}, 1 \mathrm{H}, J=3.32 \mathrm{~Hz}, \mathrm{H}-1), 7.54(\mathrm{t}, 1 \mathrm{H}, J=3.32 \mathrm{~Hz}$, Py), $7.64(\mathrm{t}, 1 \mathrm{H}, J=7.76 \mathrm{~Hz}, \mathrm{Py}), 8.13(\mathrm{~d}, 1 \mathrm{H}$, $J=3.32, \mathrm{Py}), 9.09(\mathrm{~d}, 1 \mathrm{H}, J=5.54, \mathrm{Py}), 9.13(\mathrm{~s}$, 
1H, triazole); IR $\left(\mathrm{KBr}, \mathrm{cm}^{-1}\right)$ : 3078, 2987, 2926, 1622 , 1380, 1205, 1096, 1060, 865.

2.3d Synthesis of $\left[\mathrm{PdCl}_{2}(2 \mathrm{~d})\right]$ : Treatment of galactopyranose triazole $(0.066 \mathrm{~g}, 0.17 \mathrm{mmol}) \mathbf{2 d}$ with $[\mathrm{Pd}$ (COD) $\mathrm{Cl}_{2}$ ] $(0.05 \mathrm{~g}, 0.17 \mathrm{mmol})$ resulted $\mathbf{3 d}$ as yellow solid. Yield: $0.72 \mathrm{~g}(75 \%)$; mp: $240-245^{\circ} \mathrm{C}$; Anal. calc. for $\mathrm{C}_{19} \mathrm{H}_{24} \mathrm{Cl}_{2} \mathrm{~N}_{4} \mathrm{O}_{5} \mathrm{Pd}$ : C 40.34, H 4.28, N 9.90. Found: C 40.17, H 4.71, N 8.99; ${ }^{1} \mathrm{H}$ NMR (DMSO, $500 \mathrm{MHz}$ ): $\delta 1.29\left(\mathrm{~s}, 3 \mathrm{H}, \mathrm{CH}_{3}\right.$ of $\left.\mathrm{CMe}_{2}\right), 1.38\left(\mathrm{~s}, 3 \mathrm{H}, \mathrm{CH}_{3}\right.$ of $\left.\mathrm{CMe}_{2}\right), 1.44$ (s, 3H, $\mathrm{CH}_{3}$ of $\left.\mathrm{CMe}_{2}\right), 1.48\left(\mathrm{~s}, 3 \mathrm{H}, \mathrm{CH}_{3}\right.$ of $\left.\mathrm{CMe}_{2}\right), 4.28(\mathrm{~d}, 1 \mathrm{H}, J=8.21 \mathrm{~Hz}, \mathrm{H}-3), 4.35-$ 4.38 (m, 2H, H-6), 4.48-4.51 (m, 2H, H-4 and H-5), $4.63-470(\mathrm{~m}, 1 \mathrm{H}, \mathrm{H}-2), 5.50(\mathrm{~d}, 1 \mathrm{H}, J=4.16 \mathrm{~Hz}, \mathrm{H}-$ 1), $7.56(\mathrm{t}, 1 \mathrm{H}, J=5.0 \mathrm{~Hz}, \mathrm{Py}), 8.09-8.14(\mathrm{~m}, 2 \mathrm{H}$, $J=7.180 \mathrm{~Hz}, \mathrm{Py}), 8.98(\mathrm{~s}, 1 \mathrm{H}$, triazole $), 9.14(\mathrm{~d}$, $1 \mathrm{H}, J=4.10 \mathrm{~Hz}, \mathrm{Py}$ ); ESI-MS (in $\left.\mathrm{CH}_{3} \mathrm{OH}\right): m / z 531$ $[(\mathrm{M}-\mathrm{Cl})+1]^{+}$; IR $\left(\mathrm{KBr}, \mathrm{cm}^{-1}\right)$ : 3085, 2983, 2925, 1624, 1456, 1380, 1069, 785.

\section{$2.4 X$-ray crystallography}

$\mathrm{X}$-ray data for the compounds was collected at room temperature using a Bruker Smart Apex CCD diffractometer with graphite monochromated $\mathrm{MoK} \alpha$ radiation $(\lambda=0.71069 \AA)$ with $\omega$-scan method. Preliminary lattice parameters and orientation matrices were obtained from four sets of frames. Integration and scaling of intensity data was accomplished using SAINT program. The structure was solved by direct methods using SHELXS97 and refinement was carried out by full-matrix least-squares technique using SHELXL97. Anisotropic displacement parameters were included for all non-hydrogen atoms. All O-bound $\mathrm{H}$ atoms of 2a were located in difference Fourier maps and their positions and isotropic displacement parameters were refined. Distance restraints were applied to $\mathrm{O}-\mathrm{H}$ with a set values of $0.89(2) \AA$. All other $\mathrm{H}$ atoms were positioned geometrically and treated as riding on their parent $\mathrm{C}$ atoms $[\mathrm{C}-\mathrm{H}=0.93-0.98 \AA$ and $\operatorname{Uiso}(\mathrm{H})=$ $1.5 \mathrm{Ueq}(\mathrm{C})$ for methyl $\mathrm{H}$ or $1.2 \mathrm{Ueq}(\mathrm{c})$ for other $\mathrm{H}$ atoms]. The methyl groups were allowed to rotate but not to tip.

\subsection{In vitro cytotoxic testing}

Cell lines used for testing in vitro cytotoxicity included HeLa derived from human cervical cancer cells (ATCC No. CCL-2), A549 derived from human alveolar adenocarcinoma epithelial cells (ATCC No. CCL-185), MDA-MB-231 derived from human breast adenocarcinoma cells (ATCC No. HTB-26), MCF7 derived from human breast adenocarcinoma cells (ATCC No
HTB-22), Neuro2a derived from mouse neuroblastoma cell line (ATCC No. CCL-131) were obtained from American Type Culture Collection, Manassas, VA, USA. All tumour cell lines were maintained in a Modified DMEM medium supplemented with $10 \%$ fetal bovine serum, along with $1 \%$ non-essential amino acids without L-glutamine, $0.2 \%$ sodium bicarbonate, $1 \%$ sodium pyruvate and $1 \%$ of antibiotic mixture $(10,000$ units penicillin and $10 \mathrm{mg}$ streptomycin per $\mathrm{mL}$ ). The cells were washed and resuspended in the above medium and $100 \mu \mathrm{L}$ of this suspension was seeded in 96 well flat bottom plates. The cells were maintained at $37^{\circ} \mathrm{C}$ in a humidified $5 \% \mathrm{CO}_{2}$ incubator (Model 2406 Shellab $\mathrm{CO}_{2}$ incubator, Sheldon, Cornelius, OR). After $24 \mathrm{~h}$ incubation, the cells were treated for 2 days with test compounds at concentrations ranging from 0.1 to $100 \mu \mathrm{M}$ in DMSO (1\% final concentration) and were assayed at the end of the $2^{\text {nd }}$ day. Each assay was performed with two internal controls: (1) an $\mathrm{IC}_{0}$ with cells only, (2) an $\mathrm{IC}_{100}$ with media only. After $48 \mathrm{~h}$ incubation, the cells were subjected to the MTT colorimetric assay $\left(5 \mathrm{mg} \mathrm{mL}^{-1}\right)$. The effect of the different test compounds on the viability of tumour cell lines was measured at the wavelength of $540 \mathrm{~nm}$ on a multimode reader (Infinite ${ }^{\circledR}$ M200, Tecan, Switzerland). The $\mathrm{IC}_{50}$ values (50\% inhibitory concentration) were calculated from the plotted absorbance data for the dose-response curves. $\mathrm{IC}_{50}$ values (in $\mu \mathrm{M}$ ) are expressed as the average of two independent experiments.

\section{Results and discussion}

\subsection{Synthesis and characterization}

The carbohydrate derived azido substrates for the intermolecular 1,3-dipolar cycloaddition were prepared by $\mathrm{S}_{\mathrm{N}}^{2}$ displacement reaction of the corresponding tosylates or mesylates with sodium azide in DMF at reflux temperatures. ${ }^{40,41}$ The corresponding triazoles $\mathbf{2 a - d}$ were prepared by the click reaction ${ }^{26}$ between sugar azide (1a-d) and 2-ethyl pyridine in the presence of copper(II) sulphate and sodium ascorbate in a mixture of $1: 1{ }^{\mathrm{t}} \mathrm{BuOH}-\mathrm{H}_{2} \mathrm{O}$ (scheme 1), in good yield. Pyridyl triazole containing benzyl group was prepared according to the literature procedure. ${ }^{29}$ The spectroscopic data and micro analytical data of all compounds were consistent with the proposed structures.

In the ${ }^{1} \mathrm{H}$ NMR spectrum, the anomeric proton of the furanose/pyranose ring appeared as doublet at around $\delta$ 5.83-5.97 ppm and the triazole proton appeared as singlet around $\delta 8.13 \mathrm{ppm}$. Protons of the gem-dimethyl group appeared as two singlets at $\delta 1.21$ and $\delta 1.34 \mathrm{ppm}$ in the case of furanose derived triazoles $\mathbf{2} \mathbf{a}-\mathbf{c}$ and four 


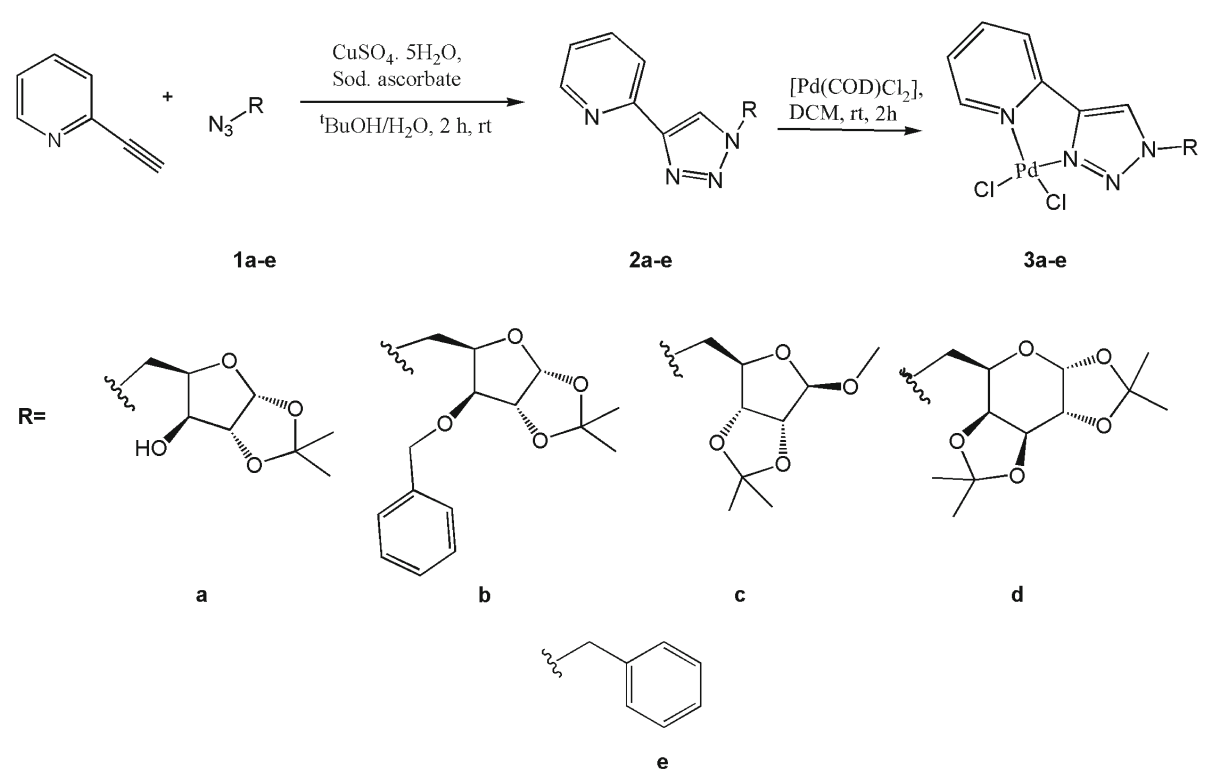

Scheme 1. Synthesis of pyridyl triazole ligands and their palladium complexes.

singlets in the case of galactose derived triazole $\mathbf{2 d}$. In the case of ribofuranosyl pyridyl triazole $\mathbf{2 c}$, the protected methyl group appeared as a sharp singlet at $\delta 3.39 \mathrm{ppm}$. The absence of IR bands corresponding to azide $\left(2095 \mathrm{~cm}^{-1}\right)$ and alkyne groups $\left(2150 \mathrm{~cm}^{-1}\right)$ further confirmed the presence of triazole ring. Compounds exhibited their characteristic stretching bands for the C-N stretching at around $1620-1640 \mathrm{~cm}^{-1}$.

The palladium complexes were prepared by reacting triazoles $\mathbf{2 a}-\mathbf{e}$ with $\left[\mathrm{Pd}(\mathrm{COD}) \mathrm{Cl}_{2}\right]$ in anhydrous dichloromethane for $2 \mathrm{~h}$ at room temperature (scheme 1). All the complexes were obtained as pale yellow powders and are soluble only in high polar solvents such as DMF and DMSO. The complexes have been fully characterized by ${ }^{1} \mathrm{H}$ NMR, ESI-MS, IR and elemental analysis. Attempts to grow single crystals of complexes yielded only a microcrystalline solid that was unsuitable for X-ray crystallographic analysis.

The characterization of the palladium complexes was done by means of ${ }^{1} \mathrm{H}$ NMR spectra recorded in $d^{6}$-DMSO solutions. The ${ }^{1} \mathrm{H}$ NMR spectra of complex $3 \mathbf{e}$ is obtained similar to the reported values. ${ }^{29}$ In ${ }^{1} \mathrm{H}$ NMR spectra of complexes $\mathbf{3 a}-\mathbf{d}$, a down field shift was observed for anomeric proton of carbohydrate scaffold as well as for the pyridyl and triazole protons. The anomeric proton of the sugar moiety appeared as doublet around 5.01-5.90 ppm depending on the sugar moiety and the protons corresponding to the two gem-isopropylidiene units of compounds $\mathbf{3 a}-\mathbf{c}$, appeared as two singlets in the region $1.27-1.31 \mathrm{ppm}$ and $1.40-1.45 \mathrm{ppm}$. For compound 3d, four singlets were observed for the four isopropylidiene units at 1.29, $1.38,1.44$ and $1.48 \mathrm{ppm}$. The triazole proton appeared as a sharp singlet around 8.5-9.0 ppm, this down field shift confirmed the complex formation.

\subsection{Crystal structure of $\mathbf{2 a}$}

The molecular structure of the pyridyl triazole 2a was determined by means of X-ray diffraction studies and its crystallographic data and structural refinement parameters are given in table 1.

Pale yellow crystals of $\mathbf{2 a}$ were obtained by the slow evaporation of ethyl acetate solution. The compound crystallized in the orthorhombic, space group $\mathrm{P} 2{ }_{1} 2_{1} 2_{1}$. The atom numbering scheme is given in figure 1 , which shows a perspective view of the compound $\mathbf{2 a}$.

The pertinent bond length and bond angle data for this compound is listed in table 2 . The crystallographic structure reveals the orientation of the pyridine with respect to the sugar-triazole moiety. The sugar binds to $\mathrm{N}(1)$ atom of triazole through the $\mathrm{C}(5)$ carbon atom with a bond angle of $117.2^{\circ}$ and the pyridine ring has an almost 'anti' conformation with respect to the triazole ring (figure 1) as reported for the pyridyl triazole ligands. ${ }^{29}$ The $\mathrm{N}(2)-\mathrm{N}(3)$ distance of the 1,2,3-triazole is $1.32 \AA$, which is shorter than the $\mathrm{N}(3)-\mathrm{C}(10)$ $(1.36 \AA)$ and $\mathrm{N}(2)-\mathrm{N}(1)(1.35 \AA$ bonds) bond distances, respectively.

\subsection{Electronic spectroscopy}

The formation of palladium complexes was further confirmed by means of absorption spectroscopic studies in $0.5 \mathrm{mM}$ DMSO solution (figure 2) over a wavelength range of $250-400 \mathrm{~nm}$. The absorption spectra of the 
Table 1. Crystallographic parameters for ligand 2a.

\begin{tabular}{ll}
\hline Crystal parameters & \\
\hline CCDC No. & 852721 \\
Empirical formula & $\mathrm{C}_{15} \mathrm{H}_{18} \mathrm{~N}_{4} \mathrm{O}_{4}$ \\
Formula weight & 318.33 \\
Temperature $(\mathrm{K})$ & $294(2)$ \\
Wavelength $(\AA)$ & 0.71069 \\
Crystal system & Orthorhombic \\
Space group & $\mathrm{P} 2{ }_{1} 2_{1} 2_{1}$ \\
$\mathrm{a} /(\AA)$ & $7.2530(6)$ \\
$\mathrm{b} /(\AA)$ & $11.0360(4)$ \\
$\mathrm{c} /(\AA)$ & $19.5230(10)$ \\
$\alpha()$ & 90.0 \\
$\beta\left({ }^{\circ}\right)$ & 90.0 \\
$\gamma\left({ }^{\circ}\right)$ & 90.0 \\
Volume $\left(\AA^{3}\right)$ & $1562.70(16)$ \\
$\mathrm{Z}$ & 4 \\
Density (calc., mg $\left.\mathrm{m}^{-3}\right)$ & 1.353 \\
$\mathrm{M}\left(\mathrm{mm}{ }^{-1}\right)$ & 0.100 \\
$\mathrm{~F}(000)$ & 672 \\
Crystal size (mm $\left.{ }^{3}\right)$ & $0.12 \times 0.17 \times 0.12$ \\
$\theta$ range & 2.09 to $25.00^{\circ}$ \\
h, k, l ranges & -8 to $8,-13$ to $13,-23$ to 23 \\
Reflection collected & 14691 \\
Independent reflection $\left[\mathrm{R}_{\text {int }}\right]$ & $1605(0.0307)$ \\
Completeness to $\theta=25.00^{\circ}$ & $100.0 \%$ \\
Refinement method & Full-matrix least square on $\mathrm{F}^{2}$ \\
Data/restraints/parameters & $1605 / 0 / 214$ \\
Goodness-of-fit-on $\mathrm{F}^{2}$ & 1.123 \\
Final $\mathrm{R}$ indices $[\mathrm{I}>2 \sigma(\mathrm{I})]$ & $\mathrm{R} 1=0.0372, \mathrm{wR} 2=0.0982$ \\
$\mathrm{R}$ indices $($ all data) & $\mathrm{R} 1=0.0411, \mathrm{wR} 2=0.1015$ \\
Absolute structure parameter & $0.004(12)$ \\
Largest diff. peak and hole $(\mathrm{e} . \AA \mathrm{A})$ & 0.408 and -0.122 \\
\hline
\end{tabular}

complexes closely resemble the UV spectra of palladium triazole complexes reported in the literature. ${ }^{29}$ All the complexes exhibited two absorption maxima around

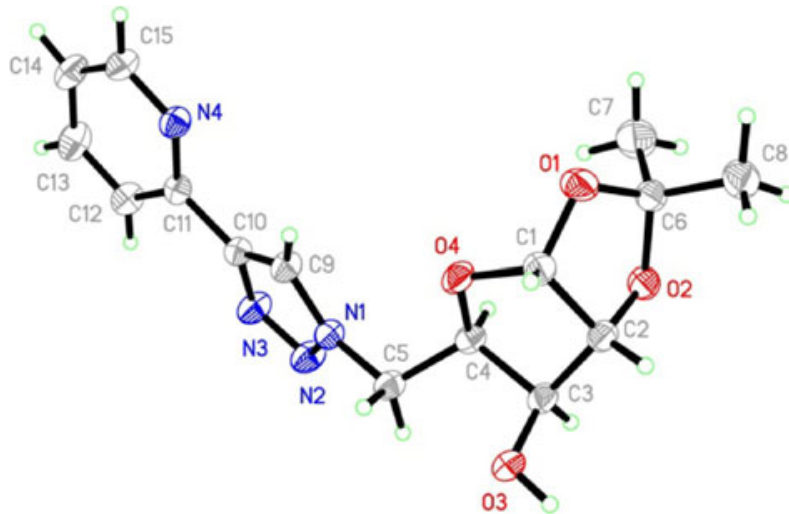

Figure 1. A view of crystal structure of $\mathbf{2 a}$, showing the atom labelling scheme. Displacement ellipsoids are drawn at the $30 \%$ probability level and the $\mathrm{H}$-atoms are represented by circles of arbitrary radii.
$280 \mathrm{~nm}$ and $310 \mathrm{~nm}$ characteristic to typical $\pi \rightarrow \pi^{*}$ charge transfer of triazole and metal to ligand charge transfer transitions (MLCT), respectively. In the UV spectra, an intense $\pi \rightarrow \pi^{*}$ transition is observed, whereas the MLCT transition is observed as a weak transition band.

Table 2. Selected bond lengths and bond angles for the compound 2a.

\begin{tabular}{llll}
\hline \multicolumn{3}{l}{ Bond lengths $(\AA)$} & \multicolumn{2}{l}{ Bond Angles $\left(^{\circ}\right)$} \\
\hline $\mathrm{C}(10)-\mathrm{C}(11)$ & $1.481(3)$ & $\mathrm{C}(4)-\mathrm{C}(5)-\mathrm{N}(1)$ & $113.8(2)$ \\
$\mathrm{C}(10)-\mathrm{N}(3)$ & $1.359(3)$ & $\mathrm{N}(1)-\mathrm{C}(9)-\mathrm{C}(10)$ & $105.3(2)$ \\
$\mathrm{N}(1)-\mathrm{N}(2)$ & $1.347(3)$ & $\mathrm{N}(1)-\mathrm{N}(2)-\mathrm{N}(3)$ & $107.3(2)$ \\
$\mathrm{N}(2)-\mathrm{N}(3)$ & $1.316(3)$ & $\mathrm{N}(3)-\mathrm{C}(10)-\mathrm{C}(11)$ & $108.2(2)$ \\
$\mathrm{C}(9)-\mathrm{N}(1)$ & $1.345(3)$ & $\mathrm{N}(3)-\mathrm{C}(10)-\mathrm{C}(9)$ & $120.8(2)$ \\
$\mathrm{N}(1)-\mathrm{C}(5)$ & $1.465(3)$ & $\mathrm{C}(11)-\mathrm{C}(10)-\mathrm{C}(9)$ & $131.0(2)$ \\
$\mathrm{C}(11)-\mathrm{N}(4)$ & $1.352(3)$ & $\mathrm{N}(4)-\mathrm{C}(11)-\mathrm{C}(10)$ & $117.2(2)$ \\
\hline
\end{tabular}




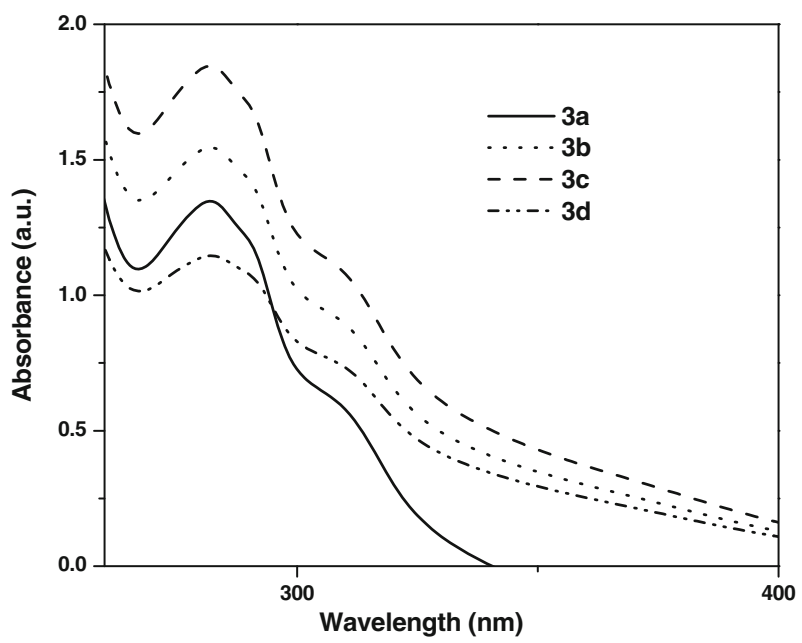

Figure 2. UV-Vis spectra of palladium complexes $\mathbf{3 a - d}$ in $0.5 \mathrm{mM}$ DMSO solutions.

\subsection{Cytotoxicity of ligands and their metal complexes (MTT assay)}

Cytotoxicity of the free triazole ligands $\mathbf{2 a - e}$ and their palladium complexes 3a-e were investigated on the basis of the measurement of in vitro growth in 96 well plates by cell mediated reduction of tetrazolium salt to form water insoluble formazan crystals according to the literature procedures ${ }^{42}$ using doxorubicin and cisplatin as standards. The compounds were tested for cytotoxicity against five different tumour cell lines: A549 (human alveolar adenocarcinoma epithelial cells), Neuro2a (mouse neuroblastoma cells), HeLa (human cervical carcinoma cancer cells), MDA-MB-231 (human breast adenocarcinoma cells) and MCF-7 (human breast adenocarcinoma cells). The concentration of compounds at which $50 \%$ of cell growth was inhibited $\left(\mathrm{IC}_{50}\right)$ was calculated and shown in table 3.

The palladium xylofuranose complex (3a) exhibited good cytotoxicity on all the cell lines with $\mathrm{IC}_{50}<10 \mu \mathrm{M}$, but the free ligand 2a was found to be non-toxic. The pyridyl triazole ligand derived from benzyl protected xylofuranose (2b), exhibited considerably high $\mathrm{IC}_{50}$ values ranging from $11.9-43.7 \mu \mathrm{M}$, whereas its palladium complex exhibited good activity with $\mathrm{IC}_{50}$ $<9 \mu \mathrm{M}$ on all the cell lines except on A549. The ribofuranose triazole ligand also found to be non-toxic but the complex 3c showed excellent cytotoxicity toward A549 $\left(\mathrm{IC}_{50}=7.68 \mu \mathrm{M}\right)$ and Neuro2a $\left(\mathrm{IC}_{50}=7.1 \mu \mathrm{M}\right)$ cell lines. Similar to ribofuranose triazole, galactopyranose triazole (2d) was also found to be non-toxic, whereas its palladium complex 3d exhibited cytotoxicity towards A549, HeLa and hormone independent breast cancer cells MDA-MB-231. In order to understand the importance of carbohydrate scaffold in these types of ligands, benzyl pyridyl triazole (2e) and its palladium complex (3e) were prepared and tested for their cytotoxicity. Interestingly, the pyridyl triazole ligand without carbohydrate moiety (2e) and the corresponding palladium complex (3e) did not show any inhibitory activity on cancer cell lines, indicating the importance of the carbohydrate scaffold in these types of complexes.

From these results it is evident that except ligand $\mathbf{2 b}$, all the carbohydrate pyridyl triazole ligands are nontoxic in nature but their palladium complexes exhibited excellent cytotoxicity. These results also show the significance of the presence of metal and carbohydrate structure in determining the cytotoxicity. The excellent cytotoxicity of carbohydrate complexes may be

Table 3. Cytotoxicity of triazoles $\mathbf{2 a - e}$ and metal complexes $\mathbf{3 a - e}$.

\begin{tabular}{llllll}
\hline \multirow{2}{*}{$\begin{array}{l}\text { Test } \\
\text { Compound }\end{array}$} & \multicolumn{5}{c}{$\mathrm{IC}_{50}(\mu \mathrm{M})$} \\
\cline { 2 - 6 } & A549 & Neuro 2a & HeLa & MDA-MBA-231 & MCF-7 \\
\hline 2a & $-^{\mathrm{a}}$ & $-^{\mathrm{a}}$ & $-^{\mathrm{a}}$ & $-^{\mathrm{a}}$ & $-^{\mathrm{a}}$ \\
$\mathbf{2 b}$ & 43.7 & 11.9 & 18.5 & 35.0 & 39.4 \\
$\mathbf{2 c}$ & $-^{\mathrm{a}}$ & $-^{\mathrm{a}}$ & $-^{\mathrm{a}}$ & $-^{\mathrm{a}}$ & $-^{\mathrm{a}}$ \\
$\mathbf{2 d}$ & $-^{\mathrm{a}}$ & $-^{\mathrm{a}}$ & $-^{\mathrm{a}}$ & $-^{\mathrm{a}}$ & $-^{\mathrm{a}}$ \\
$\mathbf{2 e}$ & $-^{\mathrm{a}}$ & $-^{\mathrm{a}}$ & $-^{\mathrm{a}}$ & $-^{\mathrm{a}}$ & $-^{\mathrm{a}}$ \\
$\mathbf{3 a}$ & 6.4 & 7.8 & 8.3 & 9.9 & 5.5 \\
$\mathbf{3 b}$ & $-^{\mathrm{a}}$ & 5.6 & 7.9 & 7.9 & 8.9 \\
$\mathbf{3 c}$ & 7.68 & 7.1 & $-^{\mathrm{a}}$ & $-^{\mathrm{a}}$ & $-^{\mathrm{a}}$ \\
$\mathbf{3 d}$ & 6.9 & $-^{\mathrm{a}}$ & 9.2 & 12.1 & $-^{\mathrm{a}}$ \\
$\mathbf{3 e}$ & $-^{\mathrm{a}}$ & $-^{\mathrm{a}}$ & $-^{\mathrm{a}}$ & $-^{\mathrm{a}}$ & $-^{\mathrm{a}}$ \\
Doxorubicin $^{\mathrm{b}}$ & 1 & $<1$ & 1.2 & $<1$ & 1 \\
Cisplatin $^{\mathrm{b}}$ & 1 & $<1$ & $<1$ & $<1$ & $<1$ \\
\hline
\end{tabular}

${ }^{\mathrm{a} N o}$ inhibiton, ${ }^{\mathrm{b}}$ standard 
attributed to the liphophilic character of the carbohydrate scaffold. The carbohydrate scaffold may be visualized in the present context as a drug delivery vehicle.

\section{Conclusions}

In conclusion, synthesis of pyridyl-sugar triazole ligands derived from different pentose and hexose sugar moieties and the corresponding palladium-triazole complexes is described. It was observed that the free ligands are non-toxic towards the tested cell lines and the insertion of metal leads to the considerable cytotoxicity. The metal complexes derived from xylofuranose moiety exhibited good cytotoxicity compared to the metal complexes of ribofuranose and galactpyranose moieties. The study clearly indicates that the insertion of metal into a non-toxic carbohydrate functional group imparts cytotoxic activity to the compound. Further experiments involving structural modifications and other biological studies to determine the role of these compounds on the apoptotic and proliferative pathways in tumour cell lines are in progress.

\section{Supporting Information}

Supporting Information contain ${ }^{1} \mathrm{H},{ }^{13} \mathrm{C}$ NMR spectra of the ligands, ${ }^{1} \mathrm{HNMR}$ spectra of the metal complexes and crystallographic date for compound 2a. CCDC 852721 contains supplementary Crystallographic data for the compound 2a. These data can be obtained free of charge via http://www.ccdc.cam.ac.uk/data_request/cif. or by emailing data_request@ccdc.cam.ac.uk, or by contacting The Cambridge Crystallographic Data Centre, 12, Union Road, Cambridge CB2 1EZ, UK; fax: +44 1223336033 .

Tables S1-S6 and figures S1-S12 can be seen in the website of Journal of Chemical Sciences (www.ias.ac. in/chemsci).

\section{Acknowledgements}

This work was financially supported by in-house project MLP-0008. Authors SBD and PS thank the Council for Scientific and Industrial Research (CSIR), New Delhi for the award of research fellowship.

\section{References}

1. Guo Z J and Sadler P J 1999 Angew. Chem. Int. Ed. 38 1512

2. Jaouen G 2006 Bioorganometallics. Weinheim: Wiley$\mathrm{VCH}$
3. Storr T, Thompson K H and Orvig C 2006 Chem. Soc. Rev. 35534

4. Hambley T W 2007 Science 3181392

5. van Rijt S H and Sadler P J 2009 Drug Discovery Today 141089

6. Dyson P J and Sava G 2006 Dalton Trans. 1929

7. Holder A A 2011 Annu. Rep. Prog. Chem., Sect. A, 107 359

8. Chen Y, Janczuk A, Chen X, Wang J, Ksebati M and Wang P G 2002 Carbohy. Res. 3371043

9. Hillard E A and Jaouen G 2011 Organometallics 30 20

10. Hartinger C G and Dyson P J 2009 Chem. Soc. Rev. 38 391-401

11. Ali M A, Mirza A H, Butcher R J, Tarafder M T H, Keat T B and Ali A M 2001 J. Inorg. Biochem. 92141

12. Padhye S, Afrasiabi Z, Sinn E, Fok J, Mehta K and Rath N 2005 Inorg. Chem. 441154

13. Al-Masoudi N A, Abdullah B H, Essa A H, Loddo R and LaColla P 2010 Arch. Pharm. Chem. Life Sci. 343 222

14. Peacock A F A and Sadler P J 2008 Chem. Asian J. 3 1890

15. Carotti S, Marcon G, Marussich M, Mazzei T, Messori L, Mini E and Orioli P 2000 Chem. Biol. Interact. 125

16. Baldini M, Belicchi-Ferrari M, Bisceglie F, Pelosi G, Pinelli S and Tarasconi P 2003 Inorg. Chem. 422049

17. Dallavalle F, Gaccioli F, Franchi-Gazzola R, Lanfranchi M, Marchio L, Pellinghelli M A and Tegoni M J 2002 Inorg. Biochem. 9295

18. Perez J M, Matesanz A I, Martin-Ambite A, Navarro P, Alonso C and Souza P J 1999 Inorg. Biochem. 75255

19. Abu-Surrah A S, Al-Sa'doni H H and Abdalla M Y 2008 Cancer Therapy 61

20. Rau T, Alsfasser R, Zahl A and van Eldik R 1998 Inorg. Chem. 374223

21. Zhao G, Lin H, Yu P, Sun H, Zhu S, Su X and Chen Y 1999 J. Inorg. Biochem. 73, 145

22. Natile G and Coluccia M 2001 Coord. Chem. Rev. 383 216 and reference therein

23. Bierbach U, Roberts J D and Farrell N 1998 Inorg. Chem. 37717

24. Tsubomura T 1990 Inorg. Chem. 292622 and reference therein

25. Chellan P, Shunmoogam-Gouden N, Hendricks D T, Gut J, Rosenthal P J, Lategan C, Smith P J, Chibale K and Smith G S 2010 Eur. J. Inorg. Chem. 3520

26. Conrad M L, Enman J E, Scales S J, Zhang H, Vogels C M, Saleh M T, Decken A and Westcott S A 2005 Inorg. Chim. Acta 63358

27. Maisonial A, Serafin P, Traïkia M, Debiton E, Théry V, Aitken D J, Lemoine P, Viossat B and Gautier A 2008 Eur. J. Inorg. Chem. 298

28. Mindt $\mathrm{T}$ L, Struthers H, Brans L, Angelov T, Schweinsberg C, Maes V, Tourwe D and Schibli R 2006 J. Am. Chem. Soc. 12815096

29. Schweinfurth D, Pattacini R, Strobel S and Sarkar B 2009 Dalton Trans. 9291

30. Kilpin K J and Crowley J D 2010 Polyhedron 293111

31. Kilpin K J, Gavey E J, McAdam C J, Anderson C B, Lind S J, Keep C C, Gordon K C and Crowley J D 2010 Inorg. Chem. 506334 
32. Rostovtsev V V, Green L G, Fokin V V and Sharpless K B 2002 Angew. Chem. Int. Ed. 412596

33. Brudziñska I, Mikata Y, Obata M, Ohtsuki C and Yano S 2004 Bioorg. Med. Chem. Lett. 142533

34. Allscher T, Klüfers P and Labisch O 2007 Carbohy. Res. 3421419

35. Cucciolito M E, Litto R D, Fanizzi F P, Migoni D, Roviello G and Ruffo F 2010 Inorg. Chim. Acta 363 741

36. Bowen M L, Chen Z F, Roos A M, Misri R, Hafeli U, Adam M J and Orvig C 2009 Dalton Trans. 9228

37. Bowen M L, Lim N C, Ewart C B, Misri R, Ferreira C L, Häfeli U, Adam M J and Orvig C 2009 Dalton Trans. 9216
38. Trivedi R, Deepthi S B, Giribabu L, Sridhar B, Sujitha P, Kumar C G and Ramakrishan K V S 2012 Eur. J. Inorg. Chem. 2267

39. Trivedi R, Deepthi S B, Giribabu L, Sridhar B, Sujitha P, Kumar C G and Ramakrishan K V S 2012 Appl. Organometal. Chem. 26369

40. Singh B K, Yadav A K, Kumar B, Gaikwad A, Sinha S K, Chaturvedi V and Tripathi R P 2008 Carbohy. Res. 3431153

41. Ferreira S B, Sodero A C R, Cardoso M F C, Lima E S, Kaiser C R, Silva F P and Ferreira Jr V F 2010 J. Med. Chem. $\mathbf{5 3} 2364$

42. Navarra M, Celano M, Maiuolo J, Schenone S, Botta M, Angelucci A, Bramanti P and Russo D 2010 BMC Cancer 10602 